\title{
Analysis Of Irfaian Odes Of Khagani Shirvani Regarding The Verses Of The Koran And The History Of The Prophets And Saints
}

Jumaeva Kamola

PhD Student Of Tashkent State University Of Oriental Studies, Tashkent, Uzbekistan

Journal Website:

https://theamericanjou

rnals.com/index.php/ta

jssei

Copyright: Original content from this work may be used under the terms of the creative commons attributes 4.0 licence.

\section{ABSTRACT}

This article below gives brief information on the literary environment in Persian classical literature in the 12th century and the entry of Irfan into the literature. Khagani Shirvani - a brilliant representative of Persian classical literature and his verses also analyzed the verses of the Qur'an and the verses referring to the history of the prophets and saints.

\section{KEYWORDS}

The Koran, hadith, Alisher Navoi, Nizami Ganjavi, Abu Hamid Ghazzali, Khagani Shirvani, Irfan, tasavvuf.

\section{INTRODUCTION}

The interest in mysticism and Irfan themes has increased in classical Persian literature, since the 12th century. If in the second half of the eleventh century the mystic poets had formed a separate group and had little influence on the poetry of the palace, at the beginning of the twelfth century, the Sana'i Ghaznavi created its work. He left the palace and began to write works on Irfan subjects. In his ode "Tasbih atTuyur", a number of his poems were devoted to this subject. Especially his work "Hadoyiq alHaqa" became famous in its time. In consequence, great talents such as Anvari, Khagani and Nizami Ganjavi contributed to the 
development of this genre [1]. This was the beginning of a new era in the development of Persian classical literature, a stage of the rise of Irfan-mystic poetry [1].

\section{MATERIALS AND METHODS}

Irfan is a peculiar commentary of the reality of the world, related to the essence of mysticism [1-4]. The study of the poets' work in this sphere, in particular, Khakani's Irfan poems showed that the knowledge of the language and traditional literature was insufficient to properly understand the works on the subject. At the time there were indeed dictionaries that were used to interpret mystic symbols by various scholars of mysticism. However, it is not easy to use the information contained in the analysis of a particular work of art. The literary researcher should be thoroughly mastered Persian-Arabic language and grammar, understood the Koranic verses with his commentaries, learned the hadiths, read the stories of saints and prophets, theoretical works of the scholars of mysticism, the principles of Shari'ah, and Islam and awareness of the literary and historical works of the poet, with the details of the history of the time and space, the various legends and stories that were common at that time, the philosophies of the time, the philosophical traditions of the people of that time and place. Otherwise, it will be difficult for the literary critic to translate and interpret the Irfan literature correctly to the reader $[5,6,8]$.

Taking into consideration the above, originally a poet of the Shirvanshahs, but after the relationship with his teacher(father-in-law) was broken, he left the palace literature and went on the Sufism-irfonic direction. We have analyzed some of the pieces of the Irfan odes of the Persian-lingual Azerbaijani poet Khagani Shirvani are analyzed in this research work.

\section{From the verses of the Koran:}

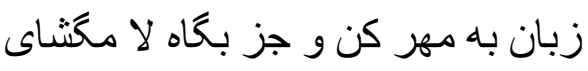

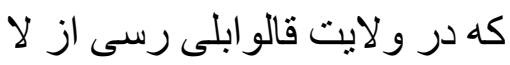

Translation:

Do not open your mouth except "Lo" and seal your tongue

The valley of "Qolu balo" you only reach with "La"

The word "Lo" referred to in this verse is "Lo" in the word "lah", "There is no god but Allah". The poet: - Do not mention anyone except for Allah. Your tongue should be opened only for the remembering of Allah. In the second line, the poet refers to the Koranic verse 172 of Surah Al-A'raf, meaning that the word "Lo" draws you closer to Allah. This is due to the fact that the above verse mentions an event called Al-Misak in Islamic history. According to it, after the creation of Adam, Allah spoke to the spirits of the human race that spread from him and said, "Alastu birabbikum" ("Am I not your Lord?"), They replied, "Qolu balo" which means ("Cannot be different"). The poet combines the denial of "Lo" in two blessed sentences, suggesting that "Lo" will make you a beloved servant of Allah.

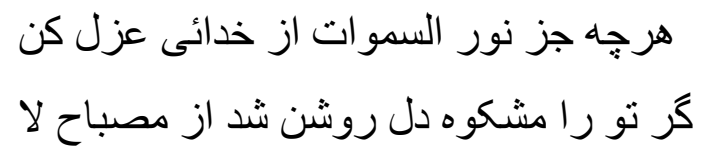

Translation: 
If the bottom of your heart is brightened by a "Lo"

In that case, you will be able to rule everything except divine light.

The poet wants to say that any desire other than the love of Allah should be restricted in your heart. The phrase "the light of the heavens" in this line refers to the Surah an-Nur of the Koran.

با تو قرب قاب قوسين آنگه افتد عشق را

كز صفات خود به بعدالمشرقين افتى جدا

Translation:

If you fall in love with Allah, when you lose your personality after the Day of Judgment, You will reach Allah as close as two eyebrows.

In the first verse above, a combination of "qurb qobe qavsin" from Sura An-Najm, 9th verset is revealed. The translator may not understand what the poet is trying to say when translating, but if he is aware of the Koran and the history of the Prophet, they will understand the meaning of a verse of the poet. According to the legend, when the Prophet Muhammad (peace be upon him) was taken up to God's Throne on the night of ascent, that the Prophet was closer as two eyebrows to Allah. Notice the word in the second verse, the word الامدسرق ين (“Al-mashriqayn”). In order to understand the meaning of the word, the literary scholar must be aware of the verses of the Koran in addition to his knowledge of the Arabic language and grammar. Allah is noted as the possessor of two east in several verses of the Koran, such as (Surah "al-Shu'ara", 6oth verset; Surah "al-Hijr",73th verset; Surah "alZuhrof", 38th verset; Surah "ar-Rahman" 17th verset). In fact, the word "east" means "the side of sunrise." Its opposite of "west" means "side of sunset." Logically, there are cannot be the word "Al-mashriqayn" that means "two east", because the sun rises on one side and sits on the other. According to Islamic belief, only on the day of doomsday, when the whole world is in turmoil, the sun will rise on both sides as a result people will not be able to find shade. Allah is the owner of that day and the Day of Judgment [2-5].

\section{From the history of the prophets and saints:}

As you know, the names of the 25 prophets are mentioned in the Koran. Some of them are uttered in the des of Khagani. In particular:

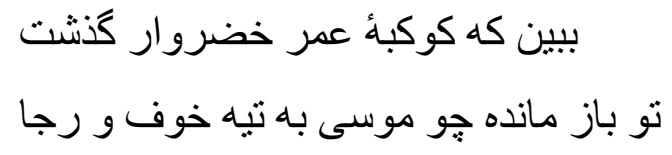

Translation:

You see, your life is passing, like Khizr,

You are astonished in the wilderness of hazard like Moses.

This couplet refers to the story of the Prophet Moses(peace be upon him) and the virtuous slave of Allah mentioned in Surah al-Kahf, in 6082 th odes. The narration consists of twentythree verses, and in Imam Bukhari's hadith in his book Jome 'as-Saheeh, that the righteous servant was Khizr [3].
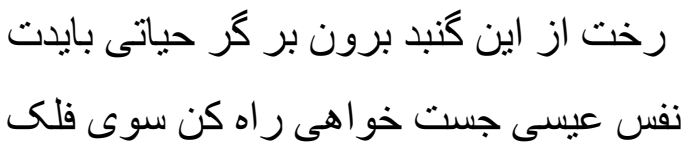

نقش عيسى در نحارستان ر اهب كن رها

Translation:

If you want to survive, get rid of your rush of this world 
If you want the spirit of Jesus, go to heaven!

Take the picture of Jesus in the monastery aside!

According to the divine books that Jesus was raised to the throne alive by Allah's power. We translated the combination of "Nigoriston" as a monastery. In Christianity, monasticism is widespread, and monks (monax in Russian) practice day and night worship in separate places known as dayrs in classical literature. According to this religious dogmas, Jesus is not a prophet, but a "son of God" as an appearance of a human being. That is why his picture (icon in Russian) is hung and prayed in the churches and monasteries. Worship of pictures is strictly prohibited in Islam [2-7].

\section{CONCLUSION}

The conclusion is that today the specialist in literature has a profound knowledge of Persian-Arabic language and grammar, his profound understanding of the Koranic verses, his knowledge of the hadith, and also awareness of the stories of the prophets and holies.

\section{REFERENCES}

1. Imomnazarov M. "Persian classical poetry of the X-XV centuries". T-2013., Page 107.

2. Ali, M. M. (2011). Holy Quran. Ahmadiyya Anjuman Ishaat Islam Lahore USA.

3. Al-Bukhari, Muhammad Bin Ismail. Jome 'as-Saheeh.

4. Hakani Shirvani. (1997). Devon (Collection). Tehran.
5. Imomnazarov M. (2016). Four doston cities on the soul. East Torch 1. pp.10-18.

6. Kamilov N. (2001). Light shining heart. Tashkent. Spirituality. Page 17.

7. Dramaturgy in Oriental Literature (Iran Dramaturgical) Teaching Methodological Complex. Tashkent. 2018. Page 11.

8. Djuraeva, D. D., \& Berdiyeva, Z. M. (2016). Cultural heritage as a factor of human development (on the example of Uzbekistan). Ученый XXI века, 23. 